\title{
Metode Estimasi Hemoglobin pada Situasi Sumberdaya Terbatas: Kajian Pustaka
}

\author{
Methods for Estimating Hemoglobin in Limited Resource Situations: \\ A Literature review
}

\author{
Mukhlissul Faatih ${ }^{1}$, Frans Dany ${ }^{2}$, Ratih Rinendyaputri ${ }^{2}$, Kambang Sariadji ${ }^{2}$, Ida Susanti ${ }^{2}$, Uly A. Nikmah ${ }^{2}$ \\ ${ }^{1}$ Pusat Penelitian dan Pengembangan Sumber Daya dan Pelayanan Kesehatan, Jalan Percetakan Negara No. 29 Jakarta \\ 10560, Indonesia \\ 2)Pusat Penelitian dan Pengembangan Biomedis dan Teknologi Dasar Kesehatan, Jalan Percetakan Negara No. 29 Jakarta \\ 10560, Indonesia \\ Korespondensi: faatih@litbang.depkes.go.id
}

Submitted: 30 April 2020, Revised: 24 Juli 2020, Accepted: 7 Agustus 2020

https://doi.org/10.22435/jpppk.v4i2.2961

\begin{abstract}
Abstrak
Ada beberapa teknik untuk mengestimasi Hemoglobin $(\mathrm{Hb})$ yang telah tersedia secara komersial. Sebagian besar metode ini tidak cocok untuk kondisi di negara berkembang dengan keterbatasan sumber daya, terutama karena harga pembelian peralatan yang tinggi atau biaya operasional yang tinggi. Kajian ini dilakukan untuk meninjau metode estimasi $\mathrm{Hb}$ yang dapat dilakukan pada situasi seumberdaya terbatas dari perspektif negara berkembang. Kajian pustaka dilakukan melalui database PubMed untuk studi-studi yang membandingkan berbagai teknik estimasi $\mathrm{Hb}$. Kajian ini mendapatkan 13 artikel yang dimasukkan dalam kajian ini. Mengestimasi $\mathrm{Hb}$ pada kondisi yang sumberdayanya terbatas diperlukan metode yang ekonomis, praktis, cepat, valid, dan handal. Cyanmethemoglobin langsung telah menjadi gold-standard untuk estimasi hemoglobin, tetapi metode lain seperti Haemoglobin Color Scale (HCS), teknik Sahli, teknik Lovibond-Drabkin, teknik Tallqvist, metode tembaga-sulfat, HemoCue ${ }^{\circledR}$, dan Automated Haematology Analyzer $(A H A)$ juga tersedia. Setiap metode memiliki prinsip kerja yang berbeda dan kelebihan serta kekurangannya masing-masing. HemoCue ${ }^{\circledR}$ adalah metode terbaik untuk skrining awal anemia karena dapat diandalkan, mudah dibawa, tidak memerlukan catu daya dan mudah digunakan dikondisi sumber daya yang kurang tanpa perlu melatih petugas kesehatan. HCS adalah metode potensial lain yang dapat digunakan dalam situasi kekurangan sumber daya. Namun, metode tersebut harus diselidiki lebih lanjut melalui studi yang lebih besar sebelum diimplementasikan.
\end{abstract}

Kata kunci: Metode estimasi hemoglobin

\begin{abstract}
There are several techniques for estimating Hemoglobin (Hb) that are commercially available. Most of these methods are not suitable for conditions in developing countries with limited resources, mainly due to equipment prices or high operational costs. This study was conducted to review the methods of estimating $\mathrm{Hb}$ which can be carried out in limited resource situations from the perspective of developing countries. $A$ literature review was carried out through the PubMed database for studies comparing various Hb estimation techniques. Results of the literature review, 13 articles were included in this review. Hb estimation in limited resources situations required methods that are not expensive, practical, quick, valid, and reliable. Direct cyanmethemoglobin has become the gold standard for estimating hemoglobin, but other methods such as Hemoglobin Color Scale (HCS), Sahli technique, Lovibond-Drabkin technique, Tallqvist technique, coppersulfate method, HemoCue ${ }^{\circledR}$, and Automated Hematology Analyzer (AHA) are also available. Each method

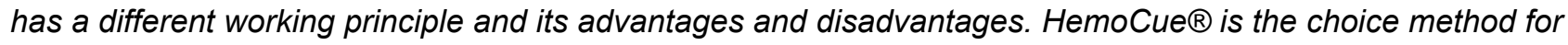


initial screening of anemia because it is reliable, portable, does not require a power supply and is easy to use in poor resource conditions without requiring health worker's training. HCS is another potential method that can be used in limited resource situations. However, these methods must be further investigated through larger studies before it's implementation.

\section{Keywords: Haemoglobin estimation method}

\section{Pendahuluan}

Pengukuran kadar hemoglobin adalah salah satu indikator yang paling dapat diandalkan untuk anemia, dan banyak digunakan untuk menyaring individu yang anemia, serta untuk mengevaluasi respon terhadap intervensi yang telah diberikan. Sebagai gold standard, kadar hemoglobin diukur menggunakan Automated Haematology Analyzer (AHA) karena sangat akurat dan dapat diandalkan, namun metode AHA mahal dan berpotensi masalah pada transportasi sampel ke laboratorium. Dalam kondisi sumber daya yang terbatas, di mana AHA tidak tersedia, metode lain dengan harga murah dan yang membutuhkan keterampilan lebih sedikit sangat dibutuhkan. Metode cyanmethemoglobin lebih murah dan sering digunakan, namun membutuhkan lebih banyak waktu. Metode tembaga sulfat $\left(\mathrm{CuSO}_{4}\right)$ gravimetri semi kuantitatif yang digunakan dalam donor darah sangat mudah dan murah, tetapi tidak memberikan tingkat akurasi yang baik. ${ }^{1}$ Beberapa metode alternatif lain yang standar juga dapat digunakan sebagai pengganti AHA.

International Committee for Standardization in Haematology (ICSH) menganjurkan pemeriksaan kadar hemoglobin metode cyanmethemoglobin, karena bersifat stabil dan bahannya relatif mudah diperoleh. ${ }^{2}$ Prinsip pemeriksaan hemoglobin dengan metode cyanmethemoglobin adalah pengubahan hemoglobin darah menjadi cyanmethemoglobin (hemoglobin sianida) dalam larutan yang berisi kalium ferrisianida $\left(\mathrm{K}_{3} \mathrm{Fe}(\mathrm{CN})_{6}\right)$ dan kalium sianida (KCN). Pemeriksaan dengan metode cyanmethemoglobin dilakukan menggunakan alat kolorimeter fotoelektrik. Absorbansi larutan diukur pada gelombang $546 \mathrm{~nm}$ (filter hijau) dengan program $\mathrm{C} / \mathrm{F}$ dan faktor 36,77. Larutan drabkin yang dipakai pada cara ini mengubah hemoglobin, oxyhemoglobin, methemoglobin dan karboksihemoglobin menjadi cyanmethemoglobin, kecuali sulfhemoglobin. ${ }^{2}$

Pada kondisi sumber daya terbatas, di mana listrik dan fasilitas lainnya terbatas, metode/ platform POC (Point of Care) mungkin berperan utama dalam proses memilih instrumen. POC adalah pemeriksaan yang dilakukan di luar lokasi laboratorium, menggunakan peralatan yang dapat dibawa dekat dengan pasien untuk mendapatkan hasil segera. ${ }^{3}$ Instrumen bertenaga baterai mungkin lebih disukai dalam kondisi seperti ini. Selain itu, stabilitas reagen pada kondisi ambien, terutama dalam panas dan kelembapan, menjadi perhatian utama di area yang akses ke laboratorium terbatas. Selain itu, metode penetapan kadar hemoglobin dengan alat hemoglobinometer portabel biasanya memerlukan waktu yang relatif singkat. Setelah mempertimbangkan risiko dan manfaat yang akan dijelaskan, memilih platform terbaik adalah langkah penting berikutnya.

$\mathrm{HemoCue}^{\circledR}$ hemoglobin fotometer sekarang banyak digunakan untuk mengatasi kekurangan turbiditas atau kekeruhan yang dijumpai pada metode cyanmethemoglobin. Sistem alat $\mathrm{HemoCue}^{\circledR}$ terdiri dari mikrokuvet siap-pakai yang mengandung reagen kering dan fotometer. Darah ditempatkan di mikrokuvet yang bereaksi dengan natrium deoksikolat, dan melisiskan eritrosit sehingga hemoglobin terlepas. Natrium nitrit lalu mengubah hemoglobin menjadi methemoglobin yang bersama dengan natrium azida, membentuk azidamethemoglobin. Absorbansi diukur pada dua panjang gelombang (565nm dan $880 \mathrm{~nm}$ ) untuk mengkompensasi kekeruhan yang timbul pada campuran reagen-spesimen., ${ }^{4,5}$ Fotometer hemoglobin HemoCue ${ }^{\circledR}$ telah banyak digunakan sebagai alat untuk estimasi hemoglobin dalam fasilitas donor darah dan di fasilitas kesehatan. ${ }^{6}$

Di Indonesia yang merupakan negara kepulauan, umumnya fasilitas kesehatan di daerah rural yang memiliki keterbatasan dalam hal pelayanan kesehatan kepada masyarakatnya. Dalam hal pelayanan untuk deteksi dan pencegahan serta penanganan anemia, diperlukan metode/platform yang sesuai untuk kondisi keterbatasan akses dan sumberdaya tersebut. Kajian pustaka ini dilakukan 
untuk meninjau metode estimasi $\mathrm{Hb}$ yang dapat bekerja terbaik dan paling sesuai pada kondisi keterbatasan sumberdaya dari perspektif negara berkembang.

\section{Metode}

Kajian pustaka ini mengidentifikasi metode estimasi $\mathrm{Hb}$ yang dapat bekerja terbaik pada kondisi keterbatasan sumberdaya dari perspektif negara berkembang melalui kajian yang komprehensif dan intepretasi dari pustaka yang berhubungan dengan topik. Metode yang digunakan pada kajian pustaka melalui pendekatan sistematis dengan menelusur artikel penelitian yang berisi hasil pengamatan di mana terdapat bagian abstrak, pendahuluan, metode, hasil dan diskusi. Pencarian literatur pada database PubMed secara online dengan kata kunci "hemoglobin OR haemoglobin", "hemoglobin estimation", "limited resources" dan kombinasi dari istilah ini. Untuk meningkatkan sensitivitas, strategi pencarian dibatasi pada spesies (manusia) dan ketersediaan artikel lengkap, selain itu hanya

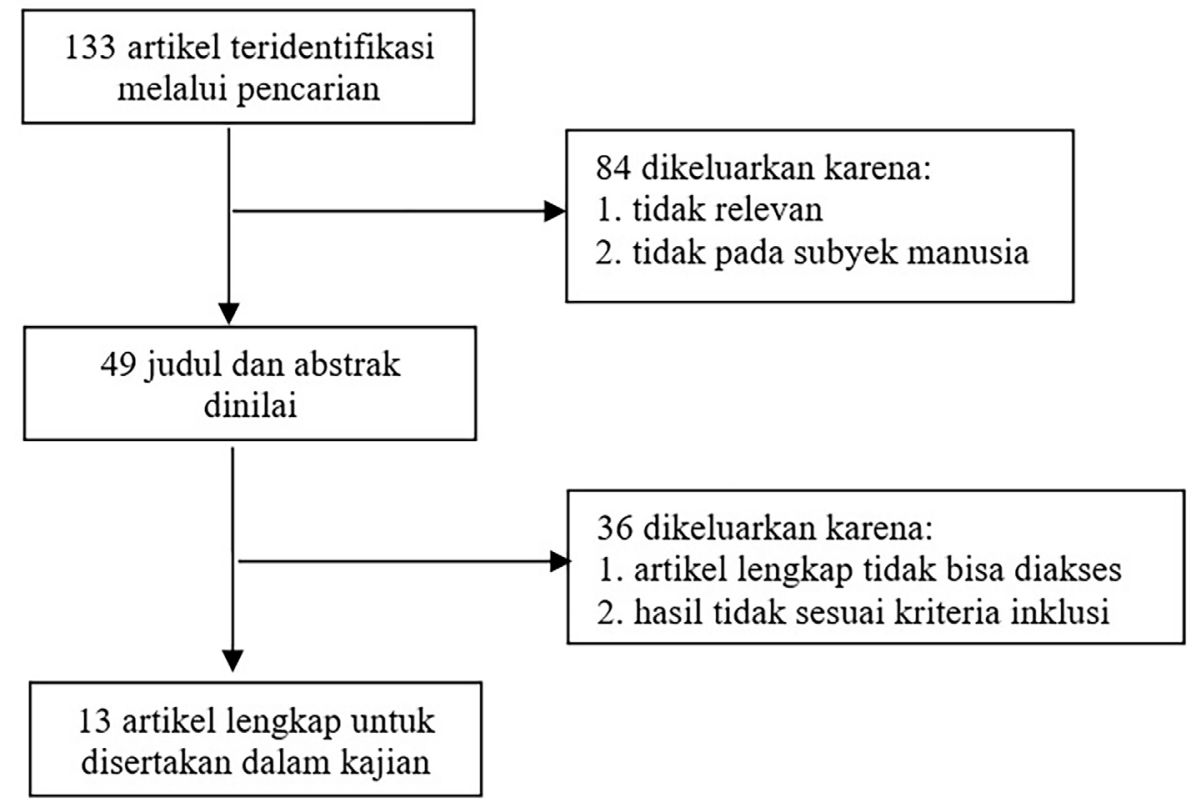

\section{Grafik 1. Alur seleksi artikel yang dimasukkan kedalam kajian}

artikel yang diterbitkan dalam bahasa Inggris yang dipertimbangkan. Kriteria yang dimasukkan untuk kajian adalah semua penelitian dengan desain observasional dan eksperimental. Penelitianpenelitian yang membandingkan estimasi $\mathrm{Hb}$ dengan metode apapun untuk mendiagnosis anemia, tidak ada batasan berdasarkan ukuran sampel, lokasi, latar belakang morbiditas, atau prevalensi anemia. Diutamakan penelitian-penelitian yang dilakukan di negara-negara berkembang dan pada kondisi keterbatasan sumberdaya. Data dari artikel penelitian yang layak kemudian diekstraksi menjadi beberapa bagian yaitu: penulis, tahun publikasi, tempat dilaksanakan penelitian dan temuan utama penelitian. Selanjutnya dilakukan analisis deskriptif, analisis kritis, dan analisis komparatif terhadap data tersebut.

\section{Hasil}

Dari pencarian baru kami melalui online database, 133 artikel diidentifikasi melalui online database PubMed untuk di-review berdasarkan judul dan abstrak. Dari jumlah tersebut, 84 artikel dikeluarkan karena tidak relevan dengan tujuan kajian. Sisanya 49 artikel dinilai untuk kelayakan dan 36 diantaranya tidak memenuhi kriteria. Kriteria inklusi dalam kajian ini adalah semua metode estimasi $\mathrm{Hb}$ yang dilakukan di negaranegara berkembang dan pada kondisi keterbatasan sumberdaya. Hasil seleksi akhir diperoleh 13 artikel lengkap yang termasuk dalam kajian ini (Grafik 1).

Estimasi hemoglobin yang cepat, valid, dan andal sangat penting untuk mendeteksi anemia pada populasi. Estimasi $\mathrm{Hb}$ bergantung pada layanan laboratorium klinis yang lengkap. Metode 
cyanmethemoglobin langsung telah menjadi gold standard untuk estimasi hemoglobin dan murah tetapi memerlukan waktu lama. Sejumlah metode lain tersedia seperti HCS, teknik Sahli, teknik LovibondDrabkin, teknik Tallqvist, metode tembaga-sulfat, HemoCue $^{\circledR}$, dan Automated Haematology Analyzer. Setiap metode memiliki prinsip kerja yang berbeda dan kelebihan serta kekurangannya sendiri. Teknik sederhana untuk mengukur $\mathrm{Hb}$ telah ada, tetapi umumnya relatif mahal dan membutuhkan reagen komersial serta keterampilan teknis yang baik untuk dapat mengintepretasikan hasil pengukuran.

Beberapa metode untuk estimasi $\mathrm{Hb}$ yang telah lama digunakan, yaitu metode Lovibond dan metode Tallqvist, telah dinyatakan tidak akurat. Dalam beberapa tahun terakhir kemajuan teknologi telah mengarah pada pengembangan perangkat baru berkembang pesat. Saat ini perangkat yang paling umum digunakan termasuk HemoCue ${ }^{\circledR}$, tembagasulfat $\mathrm{Hb}\left(\mathrm{CuSO}_{4}\right)$, dan $\mathrm{HCS}$ yang dikembangkan oleh WHO untuk digunakan di negara-negara berkembang. ${ }^{7}$ Tabel 1 di bawah menunjukkan rangkuman kelebihan, kekurangan berikut ketepatan setiap metode pengukuran hemoglobin yang saat ini sudah diketahui dan digunakan berdasarkan beberapa kepustakaan. Dari beberapa metode yang dijabarkan sebelumnya, alternatif cara pemeriksaan $\mathrm{Hb}$ seperti penggunaan $\mathrm{HCS}$ modifikasi dan hemoglobinometer portable/HemoCue ${ }^{\circledR}$ cocok digunakan pada kondisi dengan keterbatasan sumber daya dan akses pelayanan kesehatan, terutama di area rural karena kepraktisannya dan memberi hasil yang cukup akurat bila dilakukan sesuai prosedur.

\section{Pembahasan}

Beberapa metode untuk mengukur kadar hemoglobin tersebut memiliki prinsip kerja yang berbeda-beda serta memiliki kekurangan dan kelebihan masing-masing. Ada metode yang mudah namun membutuhkan reagen yang mahal serta membutuhkan keahlian khusus, hal ini dapat menyebabkan kesalahan interpretasi hasil. Penetapan kadar hemoglobin dengan metode cyanmethemoglobin merupakan gold standard untuk menentukan kadar hemoglobin dengan biaya yang relatif murah meskipun memerlukan waktu yang relatif lama. Metode lain yang dapat digunakan untuk menentukan kadar hemoglobin adalah hemoglobin color scale (HCS), metode Sahli, Lovibond-Drabkin, Talqvist, Tembagasulfat, hemoglobinometer portable $\left(\mathrm{HemoCue}^{\circledR}\right)$ dan automated haematology analyzer. Metode yang cepat dan tepat untuk mendapatkan status kadar hemoglobin merupakan hal paling vital dalam menegakkan diagnosis pada populasi yang berisiko anemia. Diagnosis yang cepat pada anemia dapat memberikan kesempatan untuk memperbaiki kondisi sehingga tidak menjadi permasalahan kesehatan yang lebih buruk.

Metode cyanmethemoglobin memiliki sensitivitas dan spesifisitas cukup tinggi, serta memberikan hasil pembacaan hasil yang stabil. Kekurangan pemeriksaan $\mathrm{Hb}$ dengan metode cyanmethemoglobin antara lain adalah kemungkinan kesalahan interpretasi atau pembacaan hasil yang dapat timbul akibat stasis vena saat pengambilan darah yang menyebabkan kadar hemoglobin lebih tinggi dari seharusnya. Selain itu, penggunaan darah kapiler menyebabkan kontaminasi cairan jaringan yang menyebabkan kadar hemoglobin lebih rendah dari seharusnya. Faktor penyebab kesalahan juga dapat terjadi karena tidak mengocok darah sewaktu mengambil bahan untuk pemeriksaan, terdapat bekuan darah, menggunakan reagen atau larutan standar yang sudah tidak baik lagi, menggunakan pipet $20 \mu \mathrm{l}$ atau 5,0 $\mathrm{ml}$ yang tidak akurat (sehingga perlu dilakukan kalibrasi pipet), cara memipet sampel darah dan reagen yang tidak tepat, spektrofotometer yang kurang baik, misalnya pengaturan panjang gelombang yang tidak tepat (karena itu perlu dilakukan kalibrasi panjang gelombang), perubahan tegangan listrik yang memengaruhi pembacaan absorbansi, darah yang lipemik (dapat menyebabkan hasil yang lebih tinggi dari seharusnya), dan keadaan leukositosis berat $(\geq 50.000 / \mu \mathrm{l})$ yang menyebabkan hasil pengukuran kadar hemoglobin lebih tinggi dari seharusnya. ${ }^{8}$

Untuk mendeteksi anemia, prinsip kerja metode HCS adalah membandingkan warna setetes darah dengan skala warna merah yang menunjukkan kadar hemoglobin yaitu pada 4, 6, 8, 10, 12 dan $14 \mathrm{~g} / \mathrm{dl}$. Setetes darah ditempatkan pada strip dan setelah 30 detik warna darah dicocokkan pada skala. Teknologi pewarna dan kertas tes strip sangat menentukan tingkat ketepatan metode ini. Melalui pengembangan teknologi dalam memilah darah 


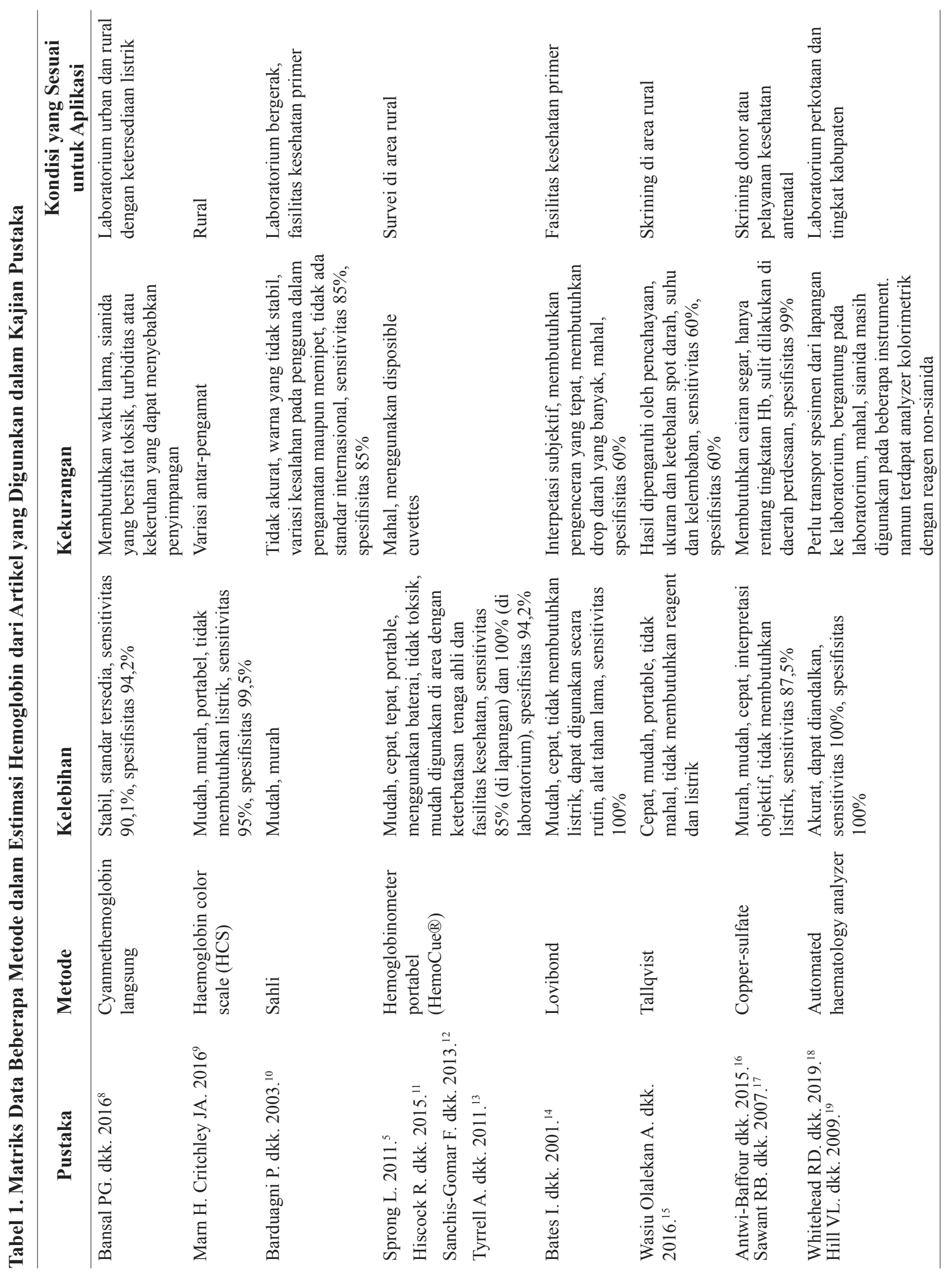


yang dapat diserap dan analisis spektrofotometri terkomputerisasi dalam mengidentifikasi warna, metode HCS kini mengalami perubahan besar. Metode HCS dapat menggantikan metode Sahli atau tembaga-sulfat dalam mengukur kadar $\mathrm{Hb}$. Selain itu pemeriksaan dengan cara ini diyakini dapat mengukur kadar $\mathrm{Hb}$ pada bayi berusia 1 hingga 4 bulan. Kelebihan metode HCS antara lain dalam hal kepraktisannya untuk digunakan di lapangan, sehingga cocok diterapkan pada pemeriksaan $\mathrm{Hb}$ di area rural dan biaya yang relatif murah. ${ }^{9}$ Meskipun demikian, kekurangan metode ini adalah terletak pada adanya subyektivitas dan variasi hasil antar pengukur.

Pada metode Sahli, hemometer (Sahli) terdiri dari alat pembanding warna, tabung pengencer, pipet darah $(20 \mu \mathrm{l})$ dan pipet pengencer darah. Kelemahan metode ini antara lain: kolorimetri secara visual tidak teliti, hematin asam bukan merupakan larutan sejati, dan alat hemometer Sahli tidak dapat distandarkan. Selain itu, tidak semua macam hemoglobin dapat diubah menjadi hematin asam, misalnya karboxyhemoglobin, methemoglobin dan sulfhemoglobin. Kesalahan juga dapat disebabkan oleh kemampuan membedakan warna yang tidak sama, sumber cahaya yang kurang baik, kelelahan mata, peralatan kurang bersih, ukuran pipet kurang tepat, perlunya kalibrasi pipet, pemipetan yang kurang akurat, dan warna gelas standar yang pucat/ kotor. Selain itu, penyesuaian warna larutan yang diperiksa dalam komparator kurang akurat. ${ }^{10}$

Cara Sahli paling banyak dipakai di Indonesia dengan tingkat kesalahan $\pm 10 \%$. Walaupun cara ini tidak memiliki ketepatan 100\%, metode Sahli masih dianggap cukup baik untuk mengetahui apakah seseorang anemia atau tidak. Prinsip pemeriksaan $\mathrm{Hb}$ cara Sahli yaitu pengubahan hemoglobin oleh asam chlorida $(0,1 \mathrm{~N})$ menjadi hematin asam yang berwarna sawo matang. Dengan air suling, warna hematin tersebut diencerkan sampai sama secara visual dengan warna standar pada hemometer dan kadar $\mathrm{Hb}$ dibaca pada tabung Sahli (tabung pengencer). ${ }^{10}$

World Health Organization (WHO) merekomendasikan pemeriksaan kadar hemoglobin untuk tujuan survei dan mengetahui prevalensi anemia adalah dengan menggunakan metode cyanmethemoglobin atau dengan metode fotometrik dengan mikrokuvet seperti sistem alat $\mathrm{HemoCue}^{\circledR}$. Pertimbangannyaadalahalatnya yang mudah dibawa, sesuai dengan kondisi di lapangan, pengumpulan sampel darah yang tidak perlu tambahan reagen lainnya kecuali mikrokuvet, tidak perlu tenaga khusus terlatih dalam mengoperasikannya, serta presisi dan akurasi yang sangat baik. ${ }^{9}$ Sistem alat $\mathrm{HemoCue}^{\circledR}$ adalah metode kuantitatif yang reliabel untuk menentukan kadar $\mathrm{Hb}$ pada survei di lapangan, yang didasari oleh metode cyanmeth. Sistem $\mathrm{HemoCue}^{\circledR}$ terdiri dari perangkat yang portable, fotometer yang diaktifkan dengan baterai, dan sejumlah kuvet untuk pengumpulan darah. Sistem ini dirancang untuk survei cepat di lapangan karena tidak perlu menambahkan larutan reagen untuk satu kali pengumpulan darah dan pengukuran $\mathrm{Hb}$. Staf survei lapangan yang bukan tenaga laboratorium pun bisa dengan mudah dilatih untuk menggunakan alat ini. ${ }^{11,12}$

Namun, penggunaan penggunaan $\mathrm{HemoCue}^{\circledR}$ menjadi sesuatu yang tidak lepas dari kelemahan alat tersebut. Misalnya, adanya pengaruh suhu lingkungan, munculnya hasil pengukuran yang di luar perkiraan tanpa konfirmasi ulang menggunakan metode cyanmenthemoglobin di laboratorium, penyimpanan reagen/strip/mikrokuvet yang tidak sesuai, kurang menjaga kebersihan alat, dan kesalahan petugas yang mengoperasikan karena tidak mempunyai latar belakang analis kesehatan. Terkadang petugas operasional tidak memperhatikan kondisi pra-analitik yang mungkin ikut memengaruhi hasil, sehingga beranggapan hasil yang keluar dari alat HemoCue ${ }^{\circledR}$ adalah hasil yang benar. Kelemahan lainnya adalah pelaksanaan quality control alat tersebut. ${ }^{5}$ Pada kondisi iklim yang sangat panas dan lembab, mikrokuvet HemoCue ${ }^{\circledR}$ tersebut tidak bisa digunakan jika telah dibiarkan dalam kondisi wadah kuvet yang terbuka dalam beberapa hari..$^{11,12,13}$

Untuk kondisi di Indonesia, negara kepulauan dengan variasi kondisi geografis yang sangat beragam dan kesulitan akses serta keterbatasan sumber daya yang masih menjadi masalah yang sangat umum ditemukan, $\mathrm{HemoCue}^{\circledR}$ dapat menjadi salah satu metode yang paling sesuai digunakan. Meskipun hal ini harus didukung dengan adanya jaminan ketersediaan reagen, strip dan mikrokuvet sampai ke seluruh pelosok Indonesia. Faktor harga juga termasuk yang perlu dipertimbangkan, karena 
strip dan mikrokuvet hanya untuk pemakaian sekali pakai. Pemerintah seyogyanya mampu meyediakan alat $\mathrm{HemoCue}^{\circledR}$ di seluruh fasilitas kesehatan serta menjamin pasokan bahan habis pakai yang diperlukan.

Metode Lovibond-Drabkin memiliki kesamaan dengan langkah-langkah pada teknik cyanmethemoglobin, di mana darah dicampur dengan larutan selama 3 menit dan warna darah yang telah terinterpolasi lalu dicocokkan dengan warna standar pada cakram. Meskipun relatif cepat, praktis dan tidak memerlukan listrik untuk pengoperasiannya, cakram yang digunakan mahal dan perkiraan saat interpretasi hasil sangat subjektif sehingga rentan terjadinya kesalahan saat pembacaan hasil. Selain itu, tetesan darah yang diperlukan juga dalam ukuran besar. Reagen yang diperlukan untuk mengencerkan darah adalah ammonia atau larutan drabkin yang sudah dimodifikasi. Baik ammonia maupun larutan drabkin yang mengandung sianida merupakan bahan kimiawi toksik yang memerlukan penanganan dan penyimpanan secara hati-hati. ${ }^{14}$

Metode Tallqvist dalam mengukur kadar $\mathrm{Hb}$ terbilang sangat sederhana, cepat dan murah. Selain tidak memerlukan listrik, reagen khusus juga tidak dipakai, melainkan dengan menggunakan kertas saring (filter) yang spesifik. Prinsip kerja cara ini adalah dengan membandingkan darah asli dengan suatu skala warna yang bertingkat-tingkat mulai dari warna merah muda sampai warna merah tua (mulai $10 \%$ sampai $100 \%$ ). Sebagai patokan perhitungan dasar, nilai $100 \%$ setara dengan 15,8 gram $\mathrm{Hb}$ per $100 \mathrm{ml}$ darah. Namun, cara ini tidak cukup teliti dalam menentukan kadar $\mathrm{Hb}$ dengan tingkat kesalahan antara $25-50 \%$. Kesalahan yang timbul dapat disebabkan faktor subyektivitas pengukur, keterbatasan stok kertas filter khusus karena kertas biasa tidak dapat digunakan dan tidak terstandar. Analisis hasil pembacaan juga dapat dipengaruhi faktor pencahayaan, ukuran dan ketebalan tetesan darah, suhu dan kelembaban. Tetesan darah pada kertas filter harus dibaca dalam rentang waktu cepat (10-15 menit) karena warna tetesan cenderung semakin gelap dengan proses pengeringan darah. ${ }^{15}$ Karena kekurangannya tersebut, metode ini kurang dipertimbangkan sebagai salah satu metode penentuan kadar $\mathrm{Hb}$ di Indonesia.

Metode Tembaga-Sulfat $\left(\mathrm{CuSO}_{4}\right)$ sering digunakan untuk menetapkan kadar $\mathrm{Hb}$ dari donor yang diperlukan untuk transfusi darah. Untuk pemeriksaan klinik metode ini jarang digunakan karena tidak memberikan hasil kuantitatif sehingga kurang tepat dan sangat subjektif. Hasil metode ini dibaca dalam persentase $\mathrm{Hb}$. Kadar $\mathrm{Hb}$ seorang donor dianggap cukup bila nilainya sekitar $80 \%$ $\mathrm{Hb}$. Tes ini dilakukan dengan meneteskan darah kapiler 1 tetes di atas permukaan larutan $\mathrm{CuSO}_{4}$ Bj 1,053 dengan volume 300-500 $\mathrm{ml}$ di dalam gelas takar. Setelah diteteskan, dilihat apakah darah terapung, melayang atau terbenam. Darah terapung menunjukkan bahwa kadar $\mathrm{Hb}$ kira-kira $<80 \%$. Darah melayang menunjukkan kadar $\mathrm{Hb}$ kira-kira berkisar $80 \%$, sedangkan darah terbenam menunjukkan kadar $\mathrm{Hb}$ di atas $80 \% .{ }^{12}$ Pada referensi lain, kategori hasil pembacaan adalah kisaran nilai $\mathrm{Hb}$ di bawah $80 \mathrm{~g} / 1$, antara 80-100 g/1 dan di atas $100 \mathrm{~g} / \mathrm{l}$. Pada metode ini tetesan darah dibiarkan jatuh ke dalam larutan tembaga sulfat yang setara dengan berat jenis hemoglobin darah isi $100 \mathrm{~g} / \mathrm{l}$ dan pergerakan tetesan diamati. Tes diulang dengan kandungan hemoglobin $80 \mathrm{~g} / 1 .^{16}$

Meskipun relatif cepat, murah, sederhana dan objektif dibandingkan Sahli, Lovibond dan Tallqvist, metode Tembaga-Sulfat sukar diterapkan di area rural karena keterbatasan ketersediaan reagen $\mathrm{CuSO}_{4}$ yang terstandar. Metode ini juga hanya menghasilkan pembacaan dalam rentang atau kisaran nilai. Larutan $\mathrm{CuSO}_{4}$ yang baru juga harus digunakan setelah 50 kali tes karena berat jenis larutan dapat berubah seiring berjalannya waktu yang dapat memengaruhi gravitasi larutan. Selain itu, penyimpanan larutan harus diperhatikan agar $\mathrm{CuSO}_{4}$ tidak mengalami evaporasi yang dapat memengaruhi ketepatan hasil pengukuran. Penanganan limbah yang mengandung spesimen darah juga tidak bisa disamakan dengan penanganan limbah lain. ${ }^{17}$

Estimasi hemoglobin dengan metode Automated Haematology Analyzer masih menjadi gold standard untuk metode pemeriksaan lainnya dan dapat dilakukan secara rutin karena menggunakan analisis hematologi otomatis yang handal dan akurat. ${ }^{1}$ Namun, kekurangan metode ini antara lain biaya yang mahal, ketergantungan pada laboratorium dan tidak aplikatif untuk area rural. Tingkat akurasi metode yang berbasis 
prinsip kolorimetri ini mencapai $100 \%$ baik untuk sensitivitas maupun spesifisitas. Sistem otomatis ini mempunyai korelasi 0,99 dengan $\mathrm{HemoCue}^{\circledR}$. Sebagian autolyzer masih menggunakan larutan drabkin yang mengandung sianida, tetapi metode baru tanpa menggunakan reagen sianida, misalnya sodium lauril sulfat (SLS), detergen lain seperti Triton- $\mathrm{X}$ atau ammonium kuartener yang tidak setoksik sianida..$^{18,19}$

Banyak metode telah didokumentasikan dalam literatur tetapi sangat sedikit dari mereka yang cocok untuk kondisi kekurangan sumber daya di negara-negara berkembang. Dari perspektif negara-negara berkembang, HemoCue ${ }^{\circledR}$ dan HCS tampaknya menjadi metode pilihan untuk skrining awal anemia karena dapat diandalkan, portabel, tidak memerlukan catu daya dan mudah digunakan di pengaturan sumber daya yang buruk tanpa memerlukan pelatihan ekstensif petugas kesehatan (Tabel 1). Rekomendasi dari kajian yang juga harus dipertimbangkan mengenai penggunaan metode HemoCue $^{\circledR}$ dan HCS adalah dalam hal kajian keekonomisannya, masalah-masalah klinis dan peraturannya sebelum diimplementasi, perlunya pelatihan yang memadai, dan kontrol kualitas internal serta pemantauan hasil. Untuk pencegahan dan pengelolaan diagnosis dini anemia, diperlukan prasyarat berupa alat yang sederhana dan cepat untuk penilaian $\mathrm{Hb}$ yang objektif. Namun, sebelum membuat keputusan apa pun untuk penggunaan metode estimasi $\mathrm{Hb}$ dalam skala besar, harus diingat bahwa ini akan menghabiskan banyak dana. ${ }^{19}$ Oleh karena itu, metode seperti $\mathrm{HemoCue}^{\circledR}$ dan HCS memerlukan penelitian lebih lanjut dalam skala besar dan jika terbukti dapat diandalkan dapat digunakan sebagai alat untuk skrining anemia pada kondisi daerah perkotaan dan kekurangan sumber daya dalam perspektif negara berkembang.

Kajian pustaka yang telah dilakukan ini masih sederhana. Guna mempertajam kajian dan memberikan data-data yang lebih komprehensif berkaitan dengan penggunaan metode pemeriksaan $\mathrm{Hb}$ yang paling sesuai dengan kondisi Indonesia, masih diperlukan lagi adanya kajian pustaka sistematik Diharapkan kajian pustaka sistematik yang dihasilkan nantinya bisa dimanfaatkan oleh pengambil kebijakan di Kementerian Kesehatan RI.

\section{Kesimpulan}

Setiap metode estimasi $\mathrm{Hb}$ memiliki prinsip kerja yang berbeda dan kelebihan serta kekurangannya masing-masing. Pada fasilitas kesehatan primer yang melayani masyarakat di wilayah rural, skrining anemia pada kondisi yang terbatas sumberdayanya ada dua metode yang cocok. $\mathrm{HemoCue}^{\circledR}$ adalah metode terbaik untuk skrining awal penderita anemia karena dapat diandalkan sensitivitas dan spesifisitasnya, mudah dibawa, tidak memerlukan catu daya dan mudah digunakan di kondisi sumber daya yang kurang tanpa perlu melatih petugas kesehatan. Meskipun memerlukan perhatian khusus dalam hal harga keterjangkauan distribusinya sampai ke seluruh pelosok negeri. Metode HCS adalah metode potensial lain yang dapat digunakan dalam situasi lapangan, cocok diterapkan pada pemeriksaan $\mathrm{Hb}$ di area rural dan biaya yang relatif murah, karena bahan habis palai dapat diperoleh lebih mudah. Namun, metode tersebut harus dikaji lebih lanjut melalui studi yang lebih besar sebelum diimplementasikan.

\section{Kontribusi Penulis}

MF, FD, RR, KS, IS dan UAN melakukan proses pengumpulan data, menyiapkan referensi, dan menuliskan draf artikel. Seluruh penulis membaca dan menyetujui artikel final.

\section{Ucapan Terima Kasih}

Terima kasih penulis sampaikan kepada Kepala Puslitbang Biomedis dan Teknologi Dasar Kesehatan dan Kepala Puslitbang Sumber Daya dan Pelayanan Kesehatan Badan Litbang Kesehatan.

\section{Daftar Rujukan}

1. Adam I, Ahmed S, Mahmoud MH, Yassin MI. Comparison of HemoCue ${ }^{\circledR}$ hemoglobinmeter and automated hematology analyzer in measurement of hemoglobin levels in pregnant women at Khartoum hospital, Sudan. Diagn Pathol. 2012;7:30. doi:10.1186/1746-1596-730

2. Zwart A, van Assendelft OW, Bull BS, England JM, Lewis SM, Zijlstra. Recommendations for reference method for haemoglobinometry in human blood (ICSH standard 1995) 
and specifications for international haemiglobinocyanide standard. (4th edition). J Clin Pathol. 1996;49(4):271-4. doi:10.1136/ jcp.49.4.271

3. Sireci AN. Hematology testing in urgent care and resource-poor settings: an overview of point of care and satellite testing. Clin Lab Med. 2015 Mar;35(1):197-207. doi:10.1016/j. cll.2014.10.009

4. Hofland HJ. Point of Care Testing and Selftest Related Consultations in General Practices in The Netherlands: an Exploratory Study on General Practitioners' Experiences. Health Technology and Services Research (HTSR). [Theses]. Netherland: University of Twente; Juli 2010.

5. Sprongl L. Quality Assurance for the POCT Systems. Central Laboratory, Sumperc Hospital, Czech Republic. 2011

6. Zhou X, Yan H, Xing Y, Dang S, Zhuoma B, Wang D. Evaluation of a portable hemoglobin photometer in pregnant women in a high altitude area: a pilot study. BMC Public Health. 2009;9:228. doi:10.1186/1471-2458-9-228

7. Srivastava T, Negandhi H, Neogi SB, Sharma J, Saxena. Methods for hemoglobin estimation: a review of "what works". J Hematol Transfus. 2014;2(3):1028.

8. Bansal PG, Toteja GS, Bhatia N, Gupta S, Kaur M, Adhikari T, et al. Comparison of haemoglobin estimates using direct \& indirect cyanmethaemoglobin methods. Indian $J$ Med Res. 2016;144(4):566-571. doi:10.4103/09715916.200882

9. Marn H, Critchley JA. Accuracy of the WHO Haemoglobin Colour Scale for the diagnosis of anaemia in primary health care settings in lowincome countries: a systematic review and metaanalysis. Lancet Glob Health. 2016;4(4):e25165. doi:10.1016/s2214-109x(16)00005-x

10. Barduagni P, Ahmed AS, Curtale F, Raafat M, Soliman L. Performance of Sahli and colour scale methods in diagnosing anaemia among school children in low prevalence areas. Trop Med Int Health. 2003;8(7):615-8. doi:10.1046/ j.1365-3156.2003.01062.x

11. Hiscock R, Kumar D, Simmons SW. Systematic review and meta-analysis of method comparison studies of Masimo pulse co-oximeters
(Radical-7TM or Pronto-7 ${ }^{\mathrm{TM}}$ ) and $\mathrm{HemoCue}{ }^{\circledR}$ absorption spectrometers (B-Hemoglobin or 201+) with laboratory haemoglobin estimation. Anaesth Intensive Care. 2015;43(3):341-50. doi:10.1177/0310057x1504300310

12. Sanchis-Gomar F, Cortell-Ballester J, ParejaGaleano H, Banfi G, Lippi G. Hemoglobin point-of-care testing: the HemoCue system. J Lab Autom. 2013;18(3):198-205. doi:10.1177/2211068212457560

13. Tyrrell A, Worrall E, Que TN, Bates I. Cost and effectiveness comparison of two methods for screening potential blood donors for anaemia in Vietnam. Transfus Med. 2011;21(3):158-65. doi:10.1111/j.1365-3148.2010.01058.x

14. Bates I, Mundy C, Pendame R, Kadewele G, Gilks C, Squire S. Use of clinical judgement to guide administration of blood transfusions in Malawi. Trans R Soc Trop Med Hyg. 2001;95(5): 510-2. doi:10.1016/s0035-9203(01)90022-7

15. Olalekan AW, Emmanuel AO. How valid is the tallquist method in screening pregnant women with anemia in poor rural settings of southwestern Nigeria? Med J Islam Repub Iran. 2016;30:389.

16. Antwi-Baffour S, Annor DK, Adjei JK, Kyeremeh R, Kpentey G, Kyei F. Anemia in prospective blood donors deferred by the copper sulphate technique of hemoglobin estimation. BMC Hematol. 2015;15:15. doi:10.1186/ s12878-015-0035-3

17. Sawant RB, Bharucha ZS, Rajadhyaksha SB. Evaluation of hemoglobin of blood donors deferred by the copper sulphate method for hemoglobin estimation. Transfus Apher Sci. 2007 Apr;36(2):143-8. doi:10.1016/j. transci.2006.11.001

18. Whitehead Jr RD, Mei Z, Mapango C, Jefferds ED. Methods and analyzers for hemoglobin measurement in clinical laboratories and field settings. Ann N Y Acad Sci. 2019;1450(1):14771. doi:10.1111/nyas. 14124

19. Hill VL, Simpson VZ, Higgins JM, Hu Z, Stevens RA, Metcalf JA, et al. Evaluation of the performance of the Sysmex XT-2000i Hematology Analyzer with whole bloods stored at room temperature. Lab Med. 2009;40(12): 709-18. doi:10.1309/T0FJYP2RBXEHX4 